\title{
PENDAPATAN BAGI PETANI SAWAH DALAM PERSPEKTIF PRODUKTIVITAS DI DESA PANDANAN KECAMATAN DUDUK SAMPEYAN GRESIK
}

\author{
Siti A'isyah', Rahmat Agus Santoso² \\ 1,2Program Studi Manajemen, Fakultas Ekonomi dan Bisnis, \\ Universitas Muhammadiyah Gresik, Gresik, Jawa Timur, Indonesia \\ sayaaisyah8@gmail.com ${ }^{1}$, $\underline{\text { ra_santoso@umg.ac.id }}^{2}$
}

\begin{abstract}
Background - The problem faced by farmers in Pandanan village is that the size of the input (resources) is higher than the size of the output (results obtained). The results of this production affect the profits that will be obtained by farmers.

Objective - This study aims to analyze the income of farmers in Pandanan Village, Sit Sampeyan Gresik District, from a productivity perspective.

Design/Methodology/Approach - By using 5 informants who were interviewed to find the actual income in terms of labor and capital. Testing is doneusing qualitative research with descriptive analysis method.
\end{abstract}

Findings - The cause of disciplinary action information about weather conditions, interests, time scheduling and family conditions. The cause of disciplinary action by leaving early is unexpected conditions and needs for family needs, employees who do not use shoes when working hours are still ongoing due to weather conditions, healthy conditions, while employees who do not use ID cards are because employees think that the use of ID cards is only used when there is a meeting outside the office

Research implications - This research contributes to examining income from a productivity perspective in terms of labor and capital

Research limitations - This study has limited research focus, namely the meaning of income for farmers in productivity where researchers find about aspects of labor and capital in income for farmers.

Keywords: : Income, Farmers, Productivity

\begin{abstract}
Abstrak
Latar Belakang - Permasalahan yang dihadapi petani di desa Pandanan yaitu ukuran input (sumber daya) yang lebih tinggi dibandingkan ukuran output (hasil yang didapat). Hasil produksi inilah yang mempengaruhi keuntungan yang akan di dapat oleh petani.

Tujuan - Penelitian ini bertujuam melakukan analisis tentang pendapatan petani Desa Pandanan Kecamatan Duduk Sampeyan Gresik dalam perspektif produktivitas.

Desain / metodologi / pendekatan - Dengan menggunakan 5 informan yang diwawancarai untuk menemukan Pendapatan yang sebenarnya dalam aspek tenaga kerja dan modal. Pengujian dilakukan dengan menggunakan penelitian kualitatif dengan metode analisis deskriptif.

Temuan - Hasil penelitian menunjukkan bahwa keberhasilan usaha pertanian yaitu dengan adanya peningkatan hasil produksi dalam memperoleh pendapatan. Peningkatan produksi dipengaruhi oleh tenaga kerja dan penggunaan modal dalam proses kegiatan usahatani.
\end{abstract}

http://dx.doi.org/10.30587/mahasiswamanajemen.v2i01.2514

Program Studi Manajemen Universitas Muhammadiyah Gresik Jawa Timur Indonesia 
Implikasi penelitian - Penelitian ini berkontribusi untuk mentelaah pendapatan perspektif produktivitas dalam aspek tenaga kerja dan aspek modal

Batasan penelitian - Penelitian ini memiliki keterbatasan mengenai fokus penelitian yakni makna pendapatan bagi petani dalam perspektif produktivitas dimana peneliti menggali tentang aspek tenaga kerja dan modal dalam memaknai pendapatan bagi petani.

Kata kunci : Pendapatan, Petani, Produktivitas

\section{PENDAHULUAN}

Pertanian adalah kegiatan pemanfaatan sumber daya hayati seperti bercocok tanam dan budidaya hewan ternak yang dilakukan manusia untuk menghasilkan bahan pangan ataupun bahan baku industri untuk menunjang kebutuhan hidupnya. Pertanian pada mulanya merupakan sesuatu yang sederhana yakni tidak membutuhkan dasar pengetahuan yang kompleks (Khaldun, 2016). Pertanian dianggap sebagai sumber penghidupan bagi orang menengah kebawah, baik secara intelektual maupun ekonomi. Secara materi petani ingin mendapatkan keuntungan/ pendapatan dalam bentuk uang atau bisa disebut balik modal dari hasil produksi. Besar kecilnya keuntungan/ pendapatan dipengaruhi seberapa banyak hasil panen dan luas lahan yang dikelola. Semakin luas lahan yang dikelola maka semakin banyak puka hasil yang didapat. Hasil itulah yang nantinya akan dijual dan petani akan mendapat uang.

Pendapatan merupakan perhitungan banyaknya uang yang akan diterima (KBBI,2020). Dimana orang-orang memandang sebagai materi yang identik dengan uang. Dalam mendapatkan keuntungan berupa uang para pelaku usaha melakukan benyak cara untuk mencapai pendapatan semaksimal mungkin. Hal ini didukung oleh prinsip ekonomi bahwa sebuah usaha memegang prinsip pengorbanan sekecil-kecilnya untuk keuntungan yang sebesar-besarnya dan juga didukung oleh wujud pendapatan yang selama ini dinilai secara fisik berupa uang.

Para petani sawah di Desa Pandanan akan menerima pendapatan ketika dari garapan sawah yang sudah dikelola sudah bisa dipanen saat sudah waktunya. Setiap pendapatan pasti ada kerugi dan keuntungan. Keuntungan adalah kondisi dimana petani mendapatkan laba dari hasil panen sawahnya (KBBI,2020), sedangkan kerugian adalah ketika pendapatan dari hasil panen itu tidak bisa melebihi modal yang telah dikeluarkan. Petani tidak hanya menginginkan keuntungan yang besar, namun ada pertimbangan dalam memulai produksi usahatani yaitu modal. Banyak petani yang 
mengeluarkan banyak modal guna untuk mengelola lahan persawahan yang nantinya diharapkan akan mendapatkan keuntungan atau pendapatan.

Menurut Sarjono (2001:131), rasio ukuran produktivitas dapat dinyatakan dengan perhitungan output dibagi input. Output pertanian adalah hasil produksi sedangkan input pertanian adalah luas lahan. Menurut Aditya (2018) produktivitas berpengaruh terhadap pendapatan. Produktivitas mengandung arti sebagai perbandingan antara hasil yang dicapai dengan keseluruhan sumberdaya yang digunakan. Produktivitas memiliki dua dimensi. Keuntungan secara materi yang didapat petani dipengaruhi oleh hasil panen dan seberapa luas lahan yang dikelola. Semakin luas lahan yang dikelola maka hasil produksi yang didapatkan pun banyak. Hasil itulah yang nantinya akan dijual dan petanimendapatkan hasil dari penjualan berupa uang.

Produktivitas pertanian dipengaruhi oleh input dan output pertanian. Input pertanian bisa meliputi tenaga kerja, lahan, dan modal sedangkan output pertanian meliputi hasil pertanian yang dikelola yaitu padi. Produktivitas pertanian tidak lepas juga dari faktor-faktor sosial dan ekonomi yang ada disekitar. Faktor sosial yang mempengaruhi produktivitas meliputi tingkat pendidikan dan pengalaman bertani. Faktor ekonomi yang mempengaruhi produktivitas meliputi pemanfaatan teknologi yang harus diseimbangkan dengan sumber daya manusia yang ada. Lahan sawah ini masuk ke dalam input pertanian dan hasil adalah output pertanian. Input dan output inilah yang mempengaruhi hasil ukuran tingkat produktivitas pertanian. Semakin tinggi produktivitas maka semakin banyak pula keuntungan yang didapatkan.

Adapun permasalahan yang dihadapi petani di desa Pandanan yaitu ukuran input (sumber daya) yang lebih tinggi dibandingkan ukuran output (hasil yang didapat). Hasil produksi inilah yang mempengaruhi keuntungan yang akan di dapat oleh petani. Apabila hasil panen rendah maka keuntungan/pendapatan juga akan sedikit. Kita ketahui sendiri bahwa sekarang berbagai harga yang mempengaruhi pekerjaan pertanian dan kebutuhan hidup masyarakat, mulai dari harga pupuk, harga obat hama, harga perlengkapan dan peralatan pertanian dan juga kebutuhan sehari hari semakin naik. Hasil padi yang didapat tidak hanya akan dijual saja melainkan akan dijadikan bahan pokok pangannya sendiri dan keluarga.

Berdasarkan latar belakang masalah, maka rumusan dalam penelitian ini adalah 
bagaimana pendapatan perspektif produktivitas dalam aspek tenaga kerja dan aspek modal. Tujuan dalam penelitian ini adalah untuk mentelaah pendapatan perspektif produktivitas dalam aspek tenaga kerja dan aspek modal pada petani sawah di desa Pandanan.

\section{TINJAUAN PUSTAKA}

\section{Pendapatan}

Kamus Besar Bahasa Indonesia (2019) Pendapatan adalah perhitungan banyaknya uang yang akan diterima. Dalam mengukur kondisi ekonomi seseorang atau rumah tangga, salah satu konsepyang paling sering digunakan adalah melalui tingkat pendapatan. Pendapatan menunjukan seluruh uang yang diterima seseorang atau rumah tangga selama jangka waktu tertentu pada suatu kegiatan ekonomi. Dengan kata lain pendapatan juga dapat diuraikan sebagai keseluruhan penerimaan yang diterima pekerja atau buruh, baik berupa fisik maupun non fisik selama ia melakukan pekerjaannya pada suatu perusahaan, maka instansi diharapkan agar mampu memenuhi kebutuhan hidupnya.

\section{Produktivitas}

Produktivitas adalah ukuran rasio antara input dan output dari suatu proses produksi dalam periode tertentu. Besar kecilnya ukuran rasio produktivitas pertanian sangat dipengaruhi oleh input dan output. Input dari pertanian meliputi tenaga kerja, lahan pertanian, teknologi, dan modal, sedangkan output dari pertanian meliputi hasil pertanian yang dikelola misalnya padi, selain itu produktivitas di bidang pertanian juga tidak lepas dari faktor-faktor sosial ekonomi yang ada disekitarnya.

Efisiensi adalah ukuran tingkat penggunaan sumber daya dalam suatu proses. Semakin hemat/sedikit penggunaan sumber daya, maka prosesnya dikatakan semakin efisien. Proses yang efisien ditandai dengan perbaikan proses sehingga menjadi lebih murah dan lebih cepat. Efektivitas adalah ukuran tingkat pemenuhan output atau tujuan proses. Semakin tinggi pencapaian target atau tujuan proses maka dikatakan proses tersebut semakin efektif. Proses yang efektif ditandai dengan perbaikan proses sehingga menjadi lebih baik dan lebih aman. 


\section{Tenaga Kerja}

Tenaga kerja dalam usaha tani merupakan curahan tenaga yang dikeluarkan untuk usahatani sendiri atau usaha keluarga. Definisi tenaga kerja dalam ilmu ekonomi adalah suatu alat kekuatan fisik dan otak manusia, yang tidak dapat dipisahkan dari manusia dan ditujukan pada usaha produksi. Tenaga kerja adalah penduduk dalam usia kerja (berusia15-64 tahun) atau jumlah seluruh penduduk dalam suatu Negara yang dapat memproduksi barang dan jasa jika ada permintaan terhadap tenaga mereka, dan jika mereka mau berpartisipasi dalam aktifitas tersebut (Mulyadi 2017:71)

\section{Modal}

Modal dalam ilmu ekonomi didefiniskan sebagai barang atau uang yang bersama-sama faktor-faktor produksi tanah dan tenaga kerja menghasilkan barang-barang baru yaitu dalam hali ini hasil pertanian. Modal adalah barang atau uang yang bersama-sama dengan faktor produksi tanah dan tenaga kerja menghasilkan barang baru dalam hasil pertanian. Modal petani yang diluar tanah adalah ternak, cangkul, alat-alat pertanian, pupuk, bibit, pestisida, hasil panen yang belum dijual, tanaman yang masih ada di sawah. Dalam pengertian yang demikian tanah bisa dimasukkan dalam modal. Bedanya adalah tanah tidak bisa dibuat oleh manusia tapi dibuat oleh alam sedangkan yang lain dibuat oleh manusia.

\section{Framezork}

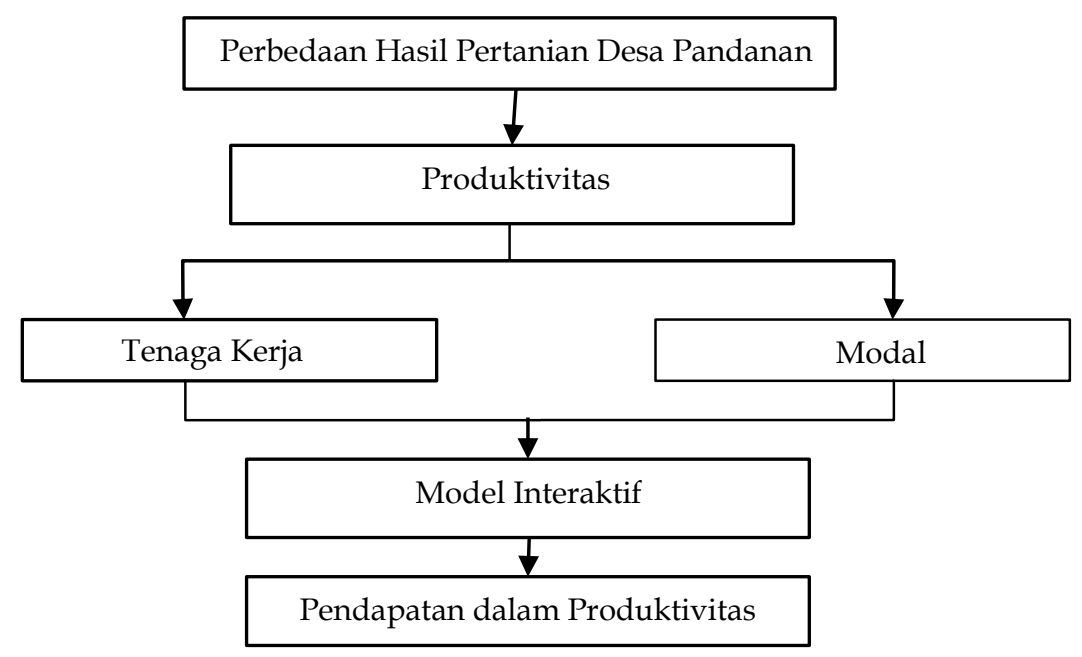

Gambar 1

Framework 


\section{METODOLOGI PENELITIAN}

\section{Pendekatan Penelitian}

Jenis penelitian ini adalah penelitian kualitatif. Penelitian kualitatif adalah penelitian yang menghasilkan prosedur analisis yang tidak menggunakan prosedur analisis statistikatau cara kuantifikasi lainnya (Moleong 2017:6).

\section{Lokasi dan Fokus Penelitian}

Lokasi penelitian merupakan tempat dimana peneliti akan melakukan penelitian. Peneliti memilih objek laha pertanian/sawahyang ada di Desa Pandanan, Kecamatan Duduk sampeyan, Kabupaten Gresik. Penelitian ini difokuskan pada pendapatan perspektif produktivitas dalam aspek tenaga kerja dan aspek modal pada petani sawah.

\section{Sumber Data dan Jenis Data}

Jenis data yang digunakan dalam penelitian ini adalah data primer. Sumber data primer dalam penelitian ini diperoleh secara langsung dari perusahaan melalui wawancara. Adapun wawancara dilakukan dengan kelompok petani yang ada di Desa Pandanan.

\section{Teknik Pengumpulan Data}

Wawancara tidak terstruktur merupakan wawancara bebas adalah wawancara yang tidakmenggunakan pedoman wawancara yang tersusun secara sistematis (Sugiyono, 2017:74). Peneliti melakukan wawanacara tidak terstuktur berdasarkan tujuan penelitian. Setelah melakukan wawancara terstruktur digunakan sebagai teknik pengumpulan data apabila peneliti sudah mengetahui secara pasti mengenai informasi yang telah di dapat. Peneliti melakukan wawancara terstruktur agar fokus pada tujuan penelitian. Berdasarkan hasil wawancara kembali secara terstruktur untuk memastikan kebenaran informasi yang di dapat dari petani di Desa Pandanan Gresik.

\section{Unit Analisis}

Unit analisis penelitian ini adalah kelompok para petani yang ada di Desa Pandanan. Teknik pengambilan sampel dilakukan menggunakan Snowball Sampling. Dibutuhkan satu informan kunci sebagai orang pertama sebelum infoman-informan selanjutnya. 


\section{Informan}

Informan utama dianggap sebagai orang yang bisa memberikan segala informasi yang dibutuhkan peneliti. Apabila sudah diperoleh seseorang yang dianggap sebagai informan utama atau Gate Keeper maka akan di dapatkan juga informan lainnya yaitu petani lain yang ditunjuk oleh informan utama yang dianggap bisa memberikan informasi yang dibutuhkan peneliti.

\section{Teknik Analisis Data}

Peneliti dalam penelitian ini menggunakan teknik analisis dataada empat tahapan yang dilakukan, antara lain pengumpulan data, reduksi data (reduction data), penyajian data (display data), penarikan kesimpulan (verification).

\section{Uji Keabsahan Data}

Member check adalah teknik keabsahan data yang diperoleh peneliti kepada pemberi data dengan tujuan untuk mengetahui seberapa jauh data yang diperoleh dan sesuai dengan yang diberikan oleh pemberi data. Tahap member check digunakan untuk mengecek keabsahan atau kebenaran data dari hasil observasi dan wawancara yangtelah terkumpul.

\section{HASIL DAN PEMBAHASAN}

\section{Pendapatan dalam aspek Tenaga Kerja}

Hasil wawancara dengan lima informan yaitu petani sawah di desa pandanan, maka bisadisimpulkan bahwa petani dalam memperoleh pendapatan dalam aspek tenaga kerja yakni sebagai berikut :

Tabel 1

Hasil Reduksi Data Pendapatan dalam aspek Tenaga Kerja

\begin{tabular}{|l|c|c|}
\hline \multirow{4}{*}{ Tenaga Kerja } & Indikator & \multirow{2}{*}{ Tema } \\
\cline { 2 - 2 } & Kemampuan & \multirow{2}{*}{ Modal Sosial } \\
\cline { 2 - 2 } & Kebutuhan & \\
\cline { 2 - 3 } & Timbal Balik & \\
\hline
\end{tabular}

Pernyataan - pernyataan diatas diambil yang terpenting kemudian disusun menjadi sub tema kemudian dijadikan tema, didapatkan dari kelima informan terkait dengan pendapatan bagi petani dalam perspektif produktivitas yakni sebagai kemampuan, kebutuhan, dan timbal balik yang mana merupakan modal sosial dalam proses kegiatan 
usahatani untuk memperoleh pendapatan. Pengggunaan buruh tani masih dipertahankan karena masih banyak orang yang memiliki kemampuan bertani dan sebaliknya petani membutuhkan bantuan dalam proses kegiatan usaha tani.

\section{Pendapatan Dalam aspek Modal}

Hasil wawancara dengan lima informan yaitu petani sawah di desa pandanan, maka bisadisimpulkan bahwa petani dalam memperoleh pendapatan dalam aspek modal yakni sebagai berikut :

Tabel 2

Hasil Reduksi Data Pendapatan Dalam aspek Modal

\begin{tabular}{|c|c|c|}
\hline \multirow{6}{*}{ Modal } & Sub Tema/Indikator & Tema \\
\hline & Pengendalian & \multirow{3}{*}{ Risiko } \\
\hline & Kendala & \\
\hline & Tambah Biaya & \\
\hline & Bertahan & \multirow{2}{*}{ Percaya Diri } \\
\hline & Hasil & \\
\hline
\end{tabular}

Sumber: Diolah Peneliti 2021

Pernyataan - pernyataan diatas diambil yang terpenting kemudian disusun menjadi sub tema kemudian dijadikan tema, didapatkan dari kelima informan terkait dengan pendapatan bagi petani dalam perspektif produktivitas aspek modal yakni sebagai petani harus berani mengambil risiko dan percaya diri untuk memperoleh (hasil) pendapatan.

Modal diperlukan untuk pengadaan sarana produksi seperti benih, pupuk, pertisida, dll. Tingginya input yang digunakan dibandingkan output yang didapatkan berpengaruh terhadap pendapatan yang diperoleh petani. Petani menggunakan biaya banyak untuk proses usaha tani dikarenakan adanya banyak kendala yang dihadapi yakni hama penyakit dan gangguan hewan liar seperti tikus dan burung. Adanya kendala-kendala yang dapat menurunkan hasil produksi, petani tetap melakukan upaya untuk mempertahankan agar mendapatkan hasil produksi. Meskipun sedikit mereka tetap menggangap itu sebagai keuntungan karena masih ada sedikit padi yang bisa dipanen yang bisa dimanfaatkan untuk kebutuhan pangan keluarga.

\section{Display Data}

\section{Proposisi 1}

Pendapatan bagi petani dalam aspek tenaga kerja adalah kemampuan, kebutuhan, dan 
timbal balik yang mana merupakan modal sosial dalam proses kegiatan usahatani untuk memperoleh pendapatan. Dalam proses pertanian pasti membutuhkan tenaga kerja yang bisa memiliki ketrampilan dalam proses kegiatan usaha tani dari mulai penanaman bibit hingga panen.

\section{Proposisi 2}

Pendapatan bagi petani dalam aspek modal adalah berani mengambil risiko dan percaya diri untuk memperoleh pendapatan. Modal merupakan faktor produksi penting dalam usaha tani. Modal pertanian bisa meliputi lahan, bibit, pupuk dan lain sebagainya. Bertambahan biaya atau modal yang dikelurakan petani biasanya terjadi apabila pertanian sedang diserang hama penyakit seperti wereng, tikus, dan burung.

\section{Proposisi Mayor}

Pendapatan bagi petani dalam perspektif produktivitas yaitu dengan menerapkan modal sosial dan tepat dalam mengambil keputusan dalam usaha mendapatkan pendapatan

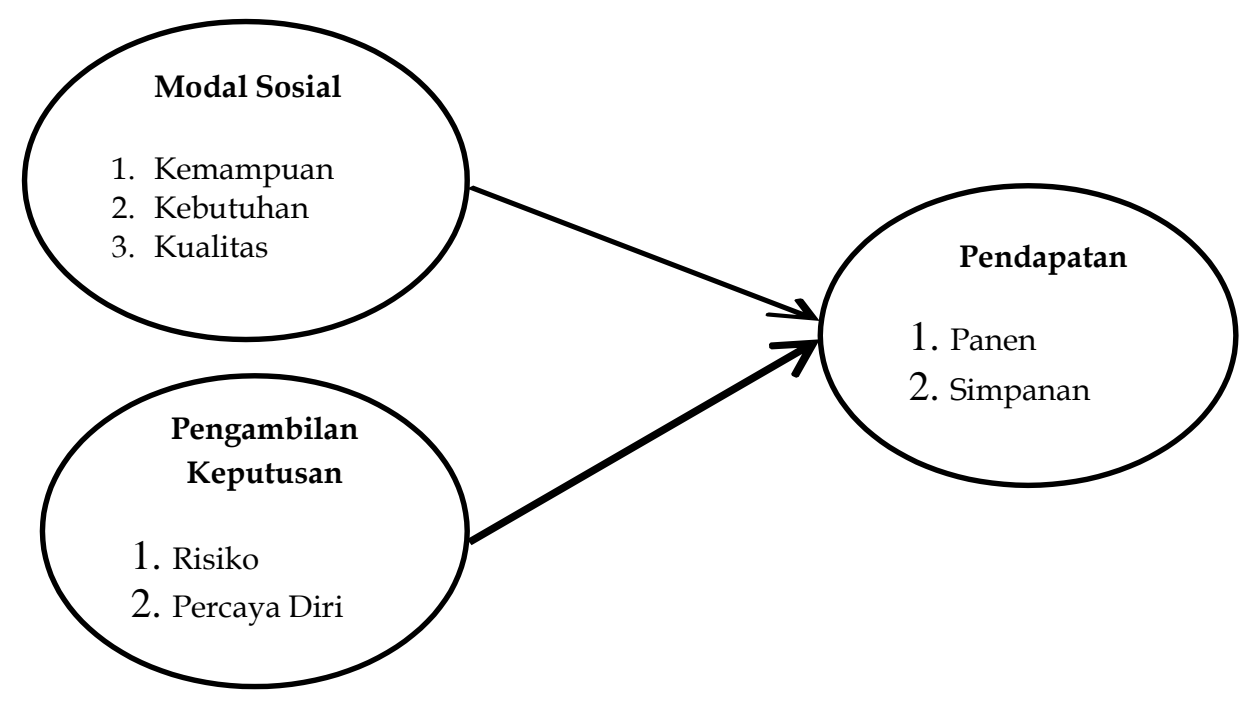

Sumber: Diolah peneliti 2021

Gambar 2 Hasil Penyajian Data

\section{Verifikasi}

1. Pemilihan penggunaan buruh tani dalam proses kegiatan pertanian ini adalah kepercayaan terhadap kemampuan yang dimiliki buruh tani agar para buruh bisa mendapatkan penghasilan dari kemampuan bertani tersebut. Penghasilan buruh 
tersebut didapatkan dari upah yang dibayarkan oleh petani yang setiap tahunnya upah buruh tani bisa saja naik.

2. Adanya kendala pertanian seperti hama penyakit mengharuskan mereka untuk membeli obat ataupun barang guna upaya pencegahan dan pemberantasan. Melakukan berbagai upaya dalam menghadapi hama adalah harapan petani agar bisa mendapatkan hasil meskipun sedikit. Hasil yang tidak sesuai dengan harapan itu tidak disesali oleh para petani karena selama mendapatkan sisa hasil panen berarti mereka bisa menggunakan hasil panen yang tidak seberapa itu untuk kebutuhan pangan mereka.

\section{Pembahasan}

Pendapatan dalam aspek tenaga kerja yang disebabkan oleh penerapan modal sosial pada kegiatan ekonomi terutama dalam bidang usahatani di Desa Pandanan. Hal tersebut sama dengan hasil penelitian dari Arrasie (2017) yang menyatakan Peningkatanproduktivitas petani dipengaruhi oleh peningkatan kualitas modal sosial. Modal sosial yang diterapkan oleh petani di Desa pandanan tidak terlepas dari kemampuan, kebutuhan dan timbal balik. Kebutuhan yang diwujudkan dengan rasa saling percaya akan tanggung jawab yang diberikan dan kemampuan atau keahlian bertani yang dimiliki buruh. Sedangkan timbal balik diwujudkan dalam bentuk memberi, saling menerima, dan saling membantu yaitu petani memberikan upah sebagai imbalan kepadaburuh tani dan petani bisa terbantu oleh buruh dalam kegiatan proses pertanian.

Pendapatan dalam aspek modal disebabkan oleh percaya diri dalam mengambil keputusan dalam menghadapi risiko pertanian Di Desa Pandanan. Hal tersebut sama dengan hasil penelitian dari Triyono \& Rahmawati (2017) yang menyatakan keberanian dalam mengambil keputusan dan risiko merupakan usaha pengelolahan pertanian. Risiko pertanian di Desa Pandanan dalam hal ini adalah petani rela menambah biaya. Biaya tambahan yang digunakan untuk membeli bibit, kebutuhan pupuk, kebutuhan obat dan biaya operasinal pertanian lainnya. 


\section{KESIMPULAN}

Berdasarkan data yang diperoleh dan diolah mengenai penelitian yang dilakukan pada Petani di Desa Pandanan, dengan berbagai macam metode atau teknik dapat disimpulkan sebagai berikut:

1. Penerapan modal sosial didasari oleh kepercayaan dan timbal balik. Tenaga kerja merupakan salah satu faktor produksi. Tenaga kerja yang digunakan dalam pertanian meliputi tenaga manusia dan mesin. Pengggunaan buruh tani masih dipertahankan karena masih banyak orang yang memiliki kemampuan bertani dan sebaliknya petanimembutuhkan bantuan dalam proses kegiatan usaha tani.

2. Percaya diri dalam pengambilan keputusan saat menghadapi risiko yakni dengan rela mengeluarkan biaya tambahan. Modal merupakan peranan penting dalam pertanian. Modal diperlukan untuk pengadaan sarana produksi seperti benih, pupuk, pertisida, dll. Tingginya input yang digunakan dibandingkan output yang didapatkan berpengaruh terhadap pendapatan yang diperoleh petani. Petani menggunakan biaya banyak untuk proses usaha tani dikarenakan adanya banyak kendala yang dihadapi yakni hama penyakit dan gangguan hewan liar seperti tikus dan burung.

\section{REKOMENDASI}

Dari kesimpulan diatas, dapat diperoleh saran yang diberikan peneliti, yakni sebagai berikut :

1. Bagi Petani

Diharapkan petani dapat lebih mengoptimalkan dalam mengelola usahanya sehingga bisa meningkatkan hasil dan bisa mendapatkan pendapatan yang maksimal. Untuk pengoptimalan usaha tani bisa dengan menggunaan teknologi sehingga bisa proses dari awal tanam hingga panen lebih efisien dan efektif.

2. Bagi Peneliti Selanjutnya

Diharapkan bagi peneliti selanjutnya dalam penelitian kualitatif dapat meneliti lebih dalam lagi tentang makna pendapatan bagi petani dalam perspektif produktivitas dengan menambahkan jumlah populasi untuk menemukan informasi mengenai produktivitas pertanian secara rinci untuk memperoleh informasi yang lebih akurat.Keabsahan data penelitian perlu ditambahkan depanditibility dan 
konfermability karena di penelitian ini hanya menggunakan kreadibility dengan member check.

\section{DAFTAR PUSTAKA}

Sarjono, H. (2001). Metode Perhitungan Angka Indeks Produktivitas Menggunakan Model Marvin E Mundel.

Mulyadi. (2017). Sistem Akuntansi. Edisi Empat. Jakarta: Salemba Empat.

Lexy J. Moleong. 2017. Metodologi Penelitian Kualitatif, Bandung: Remaja Rosdakarya.

Sugiyono. 2017. Metode penelitian kuantitatif kualitatif dan RED. Bandung: Alfabeta.

Ariessi, Nian Elly (2017).,Pengaruh Modal, Tenaga Kerja, dan Modal Sosial Terhadap Produktivitas Petani Di kecamatan Sukawati Kabupaten Gianyar. Jurnal kependudukan dan Pengembangan Sumber Daya Manusia, Vol 13, No 2.

Nur Rahmawati, Triyono. (2017). Keberanian dalam Mengambil Keputusan dan Risiko oleh Petani Padi Organik Di Kabupaten Bantu. AGRARIS: Journal of Agribussines and Rural Development Research 